\title{
Comparison of Urban and Suburban Rail Transport in Germany and in the Czech Republic ${ }^{1}$ Daniel Seidenglanz, Filip Chvátal, Kateřina Nedvědová
}

\begin{abstract}
Rail transport is an environmentally friendly form of passenger transport which can be utilized effectively also in urban and suburban transport systems. The paper describes the urban and suburban rail transport system including comparison of selected Czech (Prague, Brno and Ostrava) and German metropolitan regions (Munich, Nuremberg and Dresden). Its aim is to analyze the importance of various factors influencing the differences between the situation in Germany and in the Czech Republic. Therefore, the research question is whether these differences are primarily caused by a different liberalization stage, or whether they are a result of other factors such as available infrastructure, investment level, rail transport services budget, structure and activity of ordering bodies and coordinators or geographical context. The supply of city and suburban rail transport is quite good in Germany and in the Czech Republic, although trains in Munich, Nuremberg and Dresden run more frequently, faster and are better interconnected with car transport. German rail transport sector is at a higher stage of liberalization, and tendering procedures are the preferred selection method for contractor carriers. However, a degree of liberalization of the railway sector is not the key marker indicating a better standard of urban and suburban rail transport in Germany because it is the high standard which is achieved as the consequence of the professional activity of the ordering bodies and train service coordinators in combination with geographical conditions, available financial sources and effective transport infrastructure. On the other hand, the importance of liberalization cannot be totally overlooked as tenders are a tool for the ordering bodies to strongly affect the price and quality of transport services in their area. The supply of better quality and attractive transport to passengers could increase the usage of rail transport in metropolitan regions and could have indirect but important socio-economic impacts.
\end{abstract}

Key words: railways, urban rail transport, suburban rail transport, metropolitan region, European transport policy, liberalization, Germany, the Czech Republic

JEL Classification: R41, R48

\footnotetext{
${ }^{1}$ This paper was conceived while realizing the "Optimization of competition regulatory framework in freight and passenger railway transport in the Czech Republic" project No. TD010063 funded by the Technology Agency of the Czech Republic.

${ }^{2}$ Department of Geography, Faculty of Science, Masaryk University, Kotlářská 2, 61137 Brno, seidenglanz@geogr.muni.cz, fchvatal@mail.muni.cz, 184710@mail.muni.cz
} 


\section{Introduction - Urban and Suburban Rail Transport}

Currently, rail transport is an environmentally friendly form of passenger transport with the advantage of high transport capacity (Brinke, 1999, p. 56; Seidenglanz, 2008, p. 253). However, its usage as a percentage of the transport sector performances is quite low. Table 1 shows that the actual relative usage of rail transport in EU countries during the last two decades was around 6\%. A statement about the low significance of rail passenger transport is too general as not all market segments provide the same services and at the same standard. Many scientists emphasize that rail can be utilized most in long-distance inter-city transport systems, and in urban and suburban transport systems (Charlton, Vowles, 2008, pp.123-127; Turton, Knowles, 1998, pp. 142-146; Križan, Horňák, 2012; Horňák, Pšenka, 2013).

The best figures for transport services, including economic figures, are shown for highspeed trains that started to develop in many European countries during the past decades. A list of gradually-built high-speed railways in France, Spain, Germany and other countries is shown for example in Takagi (2005) and Givoni (2006). An accurate description of high-speed trains position on the transport market is expressed in Knowles (2006, p. 412), "... high speed trains ... enable rail to establish market leadership over air transport and cars ... on a few principal inter-urban corridors". Apart from Europe, high-speed rail transport is also widely used in eastern Asia, mainly Japan, China, South Korea and Taiwan (Takagi, 2005).

However, this article focuses on the fact that rail transport plays an important role in urban and suburban transport system of large urban centres, especially when effectively incorporated into integrated public transport systems. Then, it serves as a Spine Transport System that is connected to other feeder routes and complemented, for example, by bus transport with lower passenger capacity (Mojž̌̌š, Graja, Vančura, 2008). This way the rail transport provides passenger transport in busy radial traffic arteries where urban commuting accumulates. To be correct, this approach should be considered in the light of the deconcentration processes taking place in contemporary cities. These processes result in a relative decline of the main urban centres and relative growth of the peripheral secondary centres (for example various shopping or industrial zones). Consequently, some commuting habits are changing, as is claimed by Gutiérrez and GarcíaPalomares (2007, p. 19): "The flow networks are therefore more complex and dispersed: the trips generated by each zone are attracted by more and more zones, whilst the trips attracted by each zone are generated by a growing number of zones. The flow networks resemble a starfish-shaped structure less and less and take on the form of a spider's web with a multitude of interlaced movements". However, despite the above-mentioned changes, urban centres remain busy targets for people commuting to work, school, services, etc. In Czech geographical literature, Prague is shown as an example of a city with a high number of commuting trips from Prague hinterlands into Prague compared to all commuting trips from Prague to hinterlands and inter-hinterland trips (Urbánková, Ouředníček, 2006; Hampl, 2005). That is yet another reason why we believe that urban and suburban rail transport is currently a hot research issue, which is the reason why it is described in the following chapters of this article. 
Table 1 Performance of Passenger Transport by Mode and Year in the EU-27

\begin{tabular}{|l|r|r|r|r|r|r|}
\hline \multirow{2}{*}{ Transport mode } & \multicolumn{2}{|c|}{1995} & \multicolumn{2}{c|}{2011} & \multicolumn{2}{c|}{$\begin{array}{c}\text { Change } \\
\end{array}$} \\
\cline { 2 - 7 } & $\begin{array}{c}1000 \text { mio } \\
\text { passenger-km }\end{array}$ & $\%$ & $\begin{array}{c}1000 \text { mio } \\
\text { passenger- } \\
\text { km }\end{array}$ & $\%$ & $\begin{array}{c}1000 \text { mio } \\
\text { passenger-km }\end{array}$ & $\%$ \\
\hline Passenger cars & 3,930 & 73.3 & 4,822 & 73.4 & +892 & +0.1 \\
\hline Powered two-wheelers & 122 & 2.3 & 123 & 1.9 & +1 & -0.4 \\
\hline Bus \& coach & 499 & 9.3 & 512 & 7.8 & +13 & -1.5 \\
\hline Railway & 351 & 6.5 & 407 & 6.2 & $+\mathbf{+ 5 6}$ & -0.3 \\
\hline Tram \& subway & 71 & 1.3 & 93 & 1.4 & +22 & +0.1 \\
\hline Air & 346 & 6.5 & 575 & 8.8 & +229 & +2.3 \\
\hline Sea & 44 & 0.8 & 37 & 0.6 & -7 & -0.3 \\
\hline Total & 5,363 & 100.0 & 6,569 & 100.0 & $+1,206$ & \\
\hline
\end{tabular}

Source: European Union (2013)

According to Lejčar (2009), urban and suburban rail transport is considered to be a successful type of transport based on efficiency and ability to support busy and concentrated transport flows. In most European cities, the modern urban and suburban rail transport systems work as Through Train lines where in the city centre the lines run mostly underground. Most people head to the central station where other rail transport connections, like trams and tube, are available. Another urban and suburban rail transport advantage is that, apart from the incomparably higher passenger capacity and relatively fast access right to the city centre, the rail transport has the option to stop at suburbs of cities. Such a system was developed in Munich at the end of the 1960s and was implemented in other European cities such as Stuttgart, Frankfurt, Paris, Milan, Zurich and Leipzig in the course of the 1970s (Lejčar, 2009). A similar system is currently being implemented in London. This London project aims to support the gothrough underground lines by a new rail transport running from the East to the West End by 2018. More detailed information about this Crossrail project, including maps of the planned routes and project advantages, is available at http://www.crossrail.co.uk/.

\section{The Aim of This Study and the Method Used}

The following paper describes the organizational background of urban and suburban rail transport system in Germany and in the Czech Republic and includes a comparison of urban and suburban train supply in six selected metropolitan regions. Its aim is to analyze the importance of various factors influencing differences between the situation in Germany and in the Czech Republic. Therefore, the research question is whether these differences are caused primarily by the distinct liberalization stage, or whether they are a result of other factors such as available infrastructure, investment level, rail transport services budget, structure and activity of ordering bodies and coordinators or geographical context. The hypothesis is that the level of railway sector liberalization is one of significant components of the urban and suburban rail transport state, but is not the key marker. It could help ordering bodies and coordinators improve the level or quality of 
transport services as an effective incentive to competition between carriers, however, among other factors its importance is rather low.

The structure of the paper is such to be in accordance with its purpose. First, an organizational background of German and Czech urban and suburban rail transport systems is analyzed and compared. The term organizational background groups together conditions used in a particular country that affect mainly issues such as carrier selection and the way of planning and operation of transport services. Planning and operating of transport services is closely connected to financing system, development and maintenance of the needed infrastructure, creation and approval of the transport system concept and to many other important issues. Organizational background of urban and suburban rail transport system is currently strongly influenced by the rail transport liberalization intentions in both countries and also in selected metropolitan regions.

Second, various aspects representing the current state of urban and suburban rail transport services in Germany and in the Czech Republic were examined. Thus basic rail transport parameters in six selected metropolitan regions were compared such as a global transport concept, train frequencies, ${ }^{3}$ train speed and railway lines spatial distribution. The primary goal of these detailed case studies is to gain a deep knowledge of how the organizational background combined with some other factors like the available infrastructure affect the supply of urban and suburban rail transport services in both countries. Indicators showing the level of train operations (e.g. train frequencies overall and in different station/location types, the average train speed, the number of passengers, the availability of park\&ride facilities etc.) are presented in maps and tables included in the text.

Third, a short summary highlighting the relative importance of the factors influencing the current state of urban and suburban rail transport services in Germany and in the Czech Republic is provided at the end of the paper. This section attempts to specify the role of the railway sector liberalization among other factors, i. e. it defines the liberalization benefit for urban and suburban rail transport.

It is important to present basic methodological notes before dealing with the actual analysis. A detailed analysis of the current state of urban and suburban rail transport was made in six selected comparable metropolitan regions with similar sized core cities. Three core cities were selected in Germany (in Bavaria and Saxony) and three in the Czech Republic. The focus on these neighbouring countries and states/regions primarily has two reasons, the first being spatial proximity and long and similar historical development of settlement system, the second being geographical orientation of the financing

\footnotetext{
${ }^{3}$ When deciding individual stops train frequencies, all types and categories of trains stopping in that station were counted, including fast distance lines and regional lines. These lines stopped only in selected large towns of the hinterlands, so these tested town locations often showed higher train frequencies than small settlements being on the same route closer to the tested city (a good example is shown in Figure 2, route Munich - Augsburg).
} 
project. In each country, a representative city of primary significance in a national settlement system was selected (national metropolis with population of more than one million and with extensive and populated hinterland, specifically Munich and Prague) and two representative cities of secondary significance were selected (two mesoregional cities with population of about 300 to 500 thousand, specifically Dresden, Nuremberg, Brno and Ostrava). Basic statistical data about these cities is shown in Table 2 .

Table 2 Selected Cities in Germany and in the Czech Republic - Basic Statistical Data (2011)

\begin{tabular}{|l|l|r|r|r|r|}
\hline \multicolumn{1}{|c|}{ City } & \multicolumn{1}{|c|}{ Country } & Population & Number of jobs & $\begin{array}{c}\text { Unemployment } \\
\text { rate } \\
\text { (\%) }\end{array}$ & $\begin{array}{c}\text { GDP per capita } \\
\text { (CZK) }\end{array}$ \\
\hline Munich & Germany (Bavaria) & $1,388,308$ & 694,459 & 5.1 & 53,166 \\
\hline Prague & Czech Republic & $1,243,201$ & 600,730 & 4.4 & 41,200 \\
\hline Dresden & Germany (Saxony) & 525,105 & 223,242 & 7.9 & 20,900 \\
\hline Nuremberg & Germany (Bavaria) & 495,121 & 264,515 & 10 & 46,996 \\
\hline Brno & Czech Republic & 378,965 & 175,482 & 8.6 & 18,801 \\
\hline Ostrava & Czech Republic & 329,961 & 136,935 & 12.1 & 15,900 \\
\hline
\end{tabular}

Sources: https://www.regionalstatistik.de/genesis/online/data; http://www.czso.cz

All these cities are large urban centres with considerable regional importance and with extensive metropolitan regions. Their borders were defined quite simply for the purpose of this analysis. Their location is based on the train journey time from the central train stations (called mostly Main Train Station or Hauptbahnhof). A 60-minute train ride was set to be the maximum time limit for Munich and Prague, for the other cities like Nuremberg, Dresden, Brno and Ostrava the limit was 45 minutes. The reason for these time limits was that the longer the commuting times, the higher the unwillingness of people to commute for work or other activities. According to Novotný, Franke, Pokorná (2008) and Maier, Mulíček, Franke (2010, pp. 75-76) the maximum time that people are willing to commute daily depends on the importance and the functional size of the particular city centre. However, time limits were not totally strict, stops which exceeded the proposed limit by 1 to 3 minutes were still included in the metropolitan regions under observation.

Although the selected core cities are comparable in many statistical aspects, there is also considerable geographical variety among their metropolitan regions. The most important differences are related to their whole population and spatial size, to the resulting population density and to their work function, specifically to the number of regular work commuters (Table 3). Thus the diversity within a group of metropolitan regions is in fact bigger than among their core cities - e.g. the population of the Munich region is more than two times larger than the population of the Prague region, and a similar ratio is valid for the comparison of Nuremberg and Dresden regions to the Brno and Ostrava regions too. Busy commuting flows having tens or hundreds of thousands of people heading to all six cities, however, their intensity is higher in Germany than in the Czech Republic. Accordingly, these geographical differences of course have a major effect on the urban and suburban rail transport supply in the selected cities and we have to in- 
clude them within the group of factors explaining the variety among the intensity of railway transport in German and Czech metropolises.

Table 3 Selected Cities in Germany and in the Czech Republic and Their Metropolitan Regions (2011)

\begin{tabular}{|c|c|c|c|c|c|c|c|c|}
\hline \multirow{4}{*}{ City } & \multicolumn{3}{|c|}{ Population } & \multirow{2}{*}{\multicolumn{2}{|c|}{$\begin{array}{c}\text { Size } \\
\begin{array}{c}\text { total } \\
\text { (metropolitan } \\
\text { region) }\end{array}\end{array}$}} & \multirow{3}{*}{$\begin{array}{c}\begin{array}{c}\text { Population } \\
\text { density }\end{array} \\
\text { total (metro- } \\
\text { politan } \\
\text { region) }\end{array}$} & \multicolumn{2}{|c|}{$\begin{array}{l}\text { Commuting to work } \\
\text { to the core city }\end{array}$} \\
\hline & \multirow{3}{*}{ city } & \multirow{3}{*}{ hinterland } & \multirow{3}{*}{$\begin{array}{l}\text { total (metro- } \\
\text { politan } \\
\text { region) }\end{array}$} & & & & \multirow{3}{*}{ total } & \multirow{3}{*}{ balance } \\
\hline & & & & \multirow{2}{*}{$\begin{array}{l}\text { number } \\
\text { of } \\
\text { districts }\end{array}$} & area & & & \\
\hline & & & & & $\left(\mathrm{km}^{2}\right)$ & (people/km²) & & \\
\hline Munich & $1,388,308$ & $3,080,428$ & $4,468,736$ & 21 & $13,926.32$ & 321 & 318,014 & 188,107 \\
\hline Prague & $1,243,201$ & 912,116 & $2,155,317$ & 9 & $6,982.47$ & 309 & 163,108 & 133,693 \\
\hline Dresden & 525,105 & 1118,746 & $1,643,851$ & 5 & $7,937.29$ & 207 & $\mathrm{~N} / \mathrm{A}$ & 41,398 \\
\hline Nuremberg & 495,121 & $1,803,421$ & $2,298,542$ & 18 & $11,759.49$ & 195 & 140,957 & 91,441 \\
\hline Brno & 378,965 & 517,543 & 896,508 & 5 & $4,506 ., 13$ & 199 & 65,045 & 51,693 \\
\hline Ostrava & 329,961 & 937,346 & $1,267,307$ & 6 & $4,735.70$ & 268 & 45,266 & 32,428 \\
\hline
\end{tabular}

Note: the total extent of the metropolitan region was defined according to the rule mentioned in the text, statistical data are in all cases related to all districts connected by rail transport to specific core city.

Sources: https://www.regionalstatistik.de/genesis/online/data; http://www.czso.cz

\section{Organizational Background of Urban and Suburban Rail Transport in Ger- many and the Czech Republic}

The urban and suburban train operation in the studied cities in Germany and the Czech Republic is strongly affected by its 'organizational background'. This term is used for this article and groups together some conditions being used in the particular country that mainly affect issues such as carrier selection and the way of planning and operation of transport services. Planning and operating transport services is closely connected to the financing system, development and maintenance of the needed infrastructure, creation and approval of the transport system concept, and to many other important issues. Organizational background of urban and suburban rail transport system is currently strongly influenced by the rail transport liberalization intentions in both countries. Liberalization is applied in accordance with long-term intentions of a European Union Common Transport Policy.

According to Seidenglanz (2006, p. 38), a general goal of the EU Common Transport Policy is to achieve balanced development of the transport market encouraging the importance in environmentally-friendly types of transport, including rail transport. Rail transport liberalization is then understood as a tool leading to its revitalisation because competition of carriers will, according to EU, lead to a better and quality service for its customers. As a result, it will keep up the existing demand and stimulate new one, too.

EU rail transport liberalization started in 1991 by passing the directive No. 91/440 EU, by which the rail transport infrastructure administration and maintenance was separated from operation of the services. In the subsequent years, the EU passed several rail 
transport packages with obligatory rules of gradual opening of the EU rail transport markets. See Holvad (2009), Kvizda (2010), Tomeš (2011), Seidenglanz (2006, pp. 4041), PwC (2013), and Brandt (2006) for more details. Despite these uniform rules, there are still significant differences within the EU, and also a different liberalization pace in different EU countries. Figure 1 presents results of the so-called LIB index (Rail Liberalization Index). The figure shows that in 2011 Sweden, Great Britain, Germany and Denmark were at the top of the table. At the bottom of the table were France, Luxemburg, Latvia, Spain and Ireland (France, for instance, still has a state-run monopoly in rail passenger transport). With the LIB index of 705, the Czech Republic was in the top half of the table. The calculation of the LIB index is described in detail in the IBM Corporation (2011, pp. 30-47) study. Here, it is important to add that the LIB index is an indicator of the legislative openness of a market (the existence and importance of legal barriers preventing the external railway carrier to enter the market), not a marker of the actual competition level achieved on that market.

The Process of Rail Transport Market Liberalization in Germany started much earlier than in the Czech Republic. The independent and cross-sector agency Bundesnetzagentur is the main regulatory authority, assuring non-discriminatory access of railway carriers. The separation of infrastructure administration and maintenance from the train operation in Germany happened in 1999 when the national railway carrier Deutsche Bahn transformed into a holding company. This holding company groups together several daughter companies either running transport services (for example $D B$ Schenker Rail, DB Regio and DB Fernverkehr), or running other services - particularly the infrastructure administration and maintenance services is run by $D B$ Netz company. Other companies are $D B$ Energie or $D B$ Station\&Service. A question whether such a separation is sufficient arises as some carrier competitors sometimes criticise both the inadequate independency of the $D B N e t z$ agency on the mother holding company, and a possible favouritism of their daughter companies in the rail transport infrastructure access (IBM Corporation, 2011, p. 99-104; Nigrin, 2014).

Currently, Germany has an existing open access to passenger rail transport market as all the registered railway carriers can enter the transport market in both the long-distance market sector and the regional market sector. The regional passenger transport, including city and suburban transport that this article focuses on, is ordered by contract partners (either federal countries or various representing bodies) that sign contracts for transport services with a selected railway carrier (Läger, 2004). In 2011, the Federal Supreme Court (Bundesgerichtshof) decided that tendering procedures will be the preferred selection method for contractor carriers. As a result, the existing contracting practice of direct awards of public contracts for passenger transport services without tendering should be eliminated (e.g. see the older review by Schnell, 2001). Therefore, after expiry of the current contracts, the regional passenger transport service market will open even more and the public will benefit as all the offers will be tendered (IBM Corporation, 2011, p. 99). 
Figure 1 The 2011 LIB index results for passenger rail transport

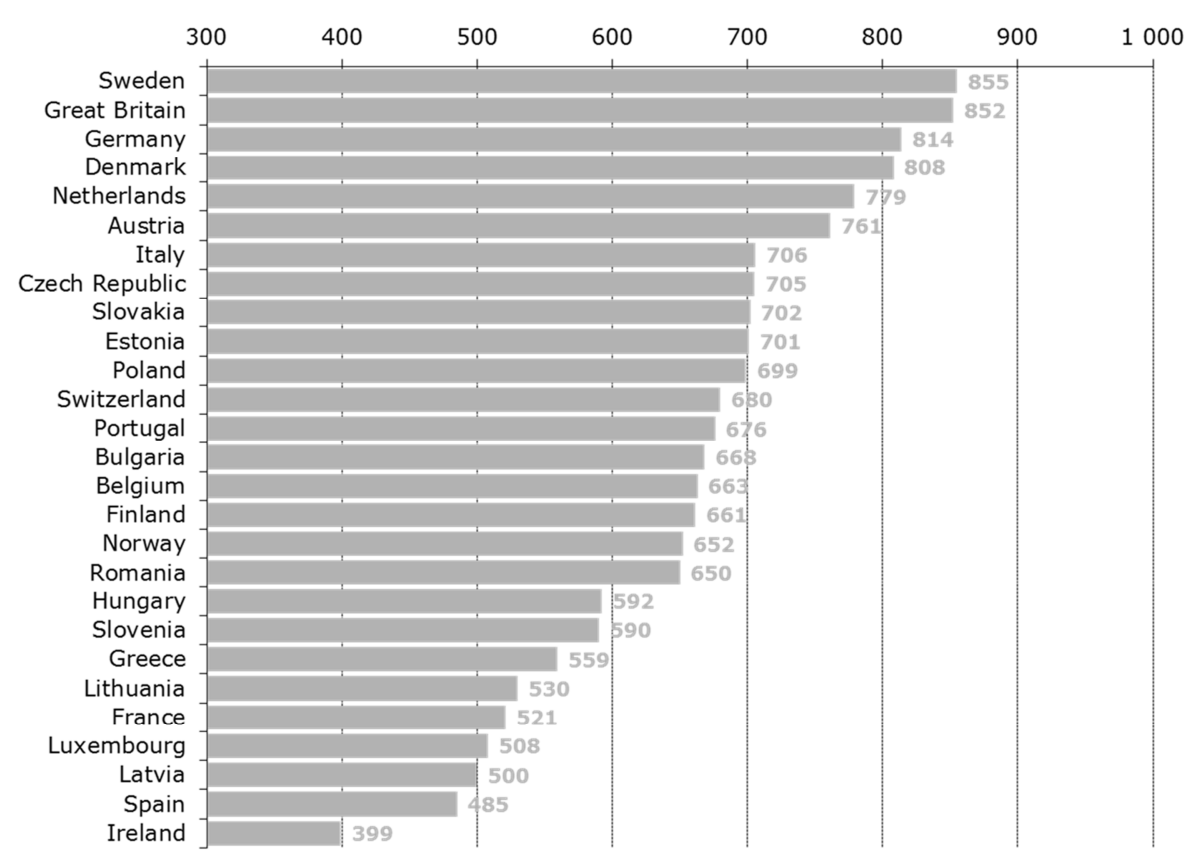

Source: IBM Corporation (2011, p. 69)

DB Regio company, a daughter company of Deutsche Bahn, is currently the biggest regional passenger railway operator in Germany. In Bavaria, the regional transport is operated by $D B$ Regio Bayern, a daughter company of $D B$ Regio, which operates the city and regional rail transport in Munich and Nuremberg by subcontracting it to another five companies. DB Regio Bayern, including its mother company Deutsche Bahn, currently runs $81 \%$ of rail transport services in Bavaria; the remaining $19 \%$ is shared by the following companies: Regentalbahn, Veolia Verkehr Regio, Erfurter Bahn, Hessische Landesbahn, Bayerische Zugspitzbahn Bergbahn, Berchtesgadener Landbahn, Hamburger Hochbahn and BeNEX (http://beg.bahnland-bayern.de/). In Saxony, particularly in the studied Dresden area, the city and regional trains are mainly operated by the DB Regio Südost company and partially by the Städtebahn Sachsen company.

The key role in organization of city and regional rail transport in Munich and Nuremberg and in their vicinities is played by the Bayerische Eisenbahngesellschaft company $(B E G)$, established in 1995 and fully owned by the federal country of Bavaria. Its main task is infrastructure planning, financing and control, and the Bavarian regional rail transport service management. The combination of planning both the infrastructure and the transport services within one company is, in our opinion, an important aspect of success as such interventions are more systematic - as infrastructure changes are done at a place where operational changes are planned as well. One of the $B E G$ 's biggest aims is to introduce relatively cheap, attractive and high quality regional rail transport services carried out in modern vehicles. The best way to achieve this is to have tenderings where 
carriers compete for the contract with $B E G$. By 2023, BEG aims to have all the regional transport in Bavaria subcontracted via tenders (24 tenderings have taken place since the rail transport reform in mid 1990s. and by 2015 , a half of the rail transport services should be subcontracted through tenders). The next tendering wave can be expected in Bavaria very soon as in 2013, all the 10-year regional transport contracts signed between BEG and DB Regio Bayern companies will expire. Similarly, in 2017, all the contracts for operating the S-Bahn systems in Munich and Nuremberg will expire as well (http://beg.bahnland-bayern.de/).

When considering the effects of tenderings on regional rail transport contracts in Germany, it is meaningful to add some experience gained during the last two decades of implementing these procedures. The crucial result of tenders obviously consists in price reduction of ordered transport services connected to the possibility of better specification of operation conditions and carriers responsibilities. The level of price reduction has reached approximately $20-30 \%$ per contract in comparison to the directly awarded orders after 2000 (Kvizda et al., 2013, pp. 58-59). Steadily growing number of tenderings and growing extent of competing units/contracts are other important findings. Nevertheless, this trend has one dangerous consequence - the number of bidders for each call for tendering is decreasing; since 2010, the average number of competitors in one call in Germany has been close to the critical lower limit of two (mofair e. V, Netzwerk Europäischer Eisenbahnen e. V, 2013). This development could be interpreted as negative because it reduces the above-mentioned positive effects of tendering procedures. Finally, it seems that the longer and economically less risky (i.e. revenue risky) the contract, the more competitors enter into the announced tendering (Hunold, Wolf, 2013; similarly Beck, 2011).

$B E G$ 's planning of transport services is systematic and, it is possible to say, also successful. By implementing the so called Bavarian tact (a tact-timetable with an increased number of lines and convenient fare innovations) and by introducing new train carriages, the number of passengers together with the transport service performance is continually increasing. Currently, 800 thousand passengers use S-Bahn trains in Munich each day, which is $25 \%$ more than in 1996. In regional transport, the number of passengers in Bavaria increased by 62\% from 1992 and purely on the Augsburg - Munich route, the demand for transport increased by 65\% between the years of 2003 and 2012 (http://beg.bahnland-bayern.de/).

The Bavarian regional rail transport is financed in $2 / 3$ by taxes and in $1 / 3$ by fare profits. In 2012, BEG paid 924.8 million euros for running the regional rail transport in Bavaria. Then the price for 1 train $\mathrm{km}$ was 7.93 Euro, or if recalculated, the total cost per one Bavarian resident is approximately 74 Euros (http://beg.bahnland-bayern.de/).

In the federal country of Saxony, the individual counties (Landkreis) and city districts (kreisfreie Stadt) are responsible for planning, organisation and implementation of their public transport. They cooperate with each other through five so-called transport associations (Verkehrsverbund), covering the entire Saxon area. Train services in Dresden and its vicinity are managed by one of the transport associations - Verkehrsverbund Oberelbe. Unlike $B E G$ that is using only rail transport, this transport association Oberelbe creates an effective public transport system that encompasses all existing means of transport. The transport association Oberelbe also has, just like $B E G$, jurisdiction over 
transport infrastructure. In 2010, the transport association Oberelbe paid 91.4 million Euros for running of the standard-gauge regional rail transport in its entire region. Price for 1 train $\mathrm{km}$ is then approximately 11 Euros, or approximately 76 Euros per one resident of the area managed by the association (http://www.vvo-online.de/; http://www.verkehr.sachsen.de/).

The Process of Rail Transport Market Liberalization in the Czech Republic started in 2003 when the separation process of the infrastructure administration and maintenance from the train operation started (Tomeš, 2009). In the same year, the Railway Infrastructure Administration (Správa železniční dopravní cesty, SŽDC) was founded, which was responsible for managing rail transport administration and maintenance, and was formally independent from the incumbent carrier (Czech Railways). The problem was that for many years, $S \check{Z} D C$ did not have sufficient personnel capacity, so many of their activities were contracted directly to Czech Railways. It was only in 2008 that $S \check{Z} D C$ took over the infrastructure maintenance and timetabling and in 2011 also took over operational and traffic control activities. Therefore, the criticism of the Czech Republic by EU, pointing out the insufficient separation of railway infrastructure management from operation, was not surprising as this action was required by the EU First Railway Package accepted already in 1991. The practices existing until 2011 enabled favouritism of Czech Railways from other competitors. Currently, the Rail Authority (Drážní úrad) is the main regulation authority in the Czech Republic. This organisation provides non-discriminatory access of carriers to the market. This office has many important jurisdictions, however, according to the IBM Corporation study (2011, pp. 9498), the powers of this office are inadequate and the office does not conduct many of their activities also due to insufficient personnel capacity.

Despite the drawbacks mentioned above, the Czech Republic currently has, from the legislation point of view, existing open access to passenger rail transport as all the registered railway carriers can enter the passenger transport market in both the long-distance and regional transport sector. In fact, the market is opened only in a small segment of commercial transport (, apart from Czech Railways, there are also other companies in this market segment, such as RegioJet and LEO express operating on the Prague - Ostrava route). The vast majority of long-distance and regional passenger rail transport in the Czech Republic, including city and suburban transport that this study focuses on, is run by public contractors. Public contracts for passenger transport services used to be preferably directly awarded without tenderings, and in almost every single case these contracts were signed with Czech Railways. Czech Railways also runs urban and suburban transport in all three tested Czech cities - Prague, Brno and Ostrava. From the information stated above it is not surprising that the LIB index for the Czech Republic was 100 points lower than the LIB index for Germany (see again Figure 1, IBM Corporation, 2011).

Regional transport in the Czech Republic is organised by individual regions - in Prague and its vicinity it is the Prague Region and the Central Bohemian Region; in Brno it is the South Moravian Region; and in Ostrava it is the Moravian-Silesian Region. Since the regions were established in 2000, each region orders their own train services and the majority of these orders are - as was already mentioned earlier - contracted to Czech Railways. The whole situation escalated in 2009, i.e. just before the bill No. 194/2010 
(the Passenger Transport Public Contract Act introducing the EU requirements for tenders when selecting rail transport carrier for public contracts) was passed, when every single region signed a 10-year contract directly, i.e. without any tendering whatsoever, with Czech Railways for operating almost all the regional trains with the option of extending this contract for another 5 years. The signature of the Memorandum about stable financing of the regional transport services was a strong incentive for signing the contracts, and strengthening the Czech Railways position on the regional transport market. This Memorandum was signed in 2009 between the Czech government and all the regions, and the idea was to provide financial governmental support to secure all the regional rail transport during 2010 - 2019. There was one condition that all the regions had to sign, in short time scale, a contract for 10 years with a selected carrier. Consequently, all the regions signed the above-mentioned contract with Czech Railways.

The contracts between regions and Czech Railways for operating the regional rail transport in 2010 - 2019 had serious consequences as by signing these contracts the regions basically gave up the options to tender for carriers that under certain specified conditions could provide, the best, most effective and most quality regional transport services in the vast majority of their areas. This decision made by the regions basically closed the regional rail transport market in the Czech Republic for 10 years, i.e. for the period of 2009 - 2019 (or until 2024 if they decide to extend the contracts by 5 years).

For Czech Railways, these contracts are very convenient as each region pays for the services of their carriers. According to the Czech Republic Ministry of Transport statistics, the regions paid a total of 8.4 billion Czech crowns for their regional passenger rail transport operation in 2012 (http://www.mdcr.cz/cs/verejna-doprava/prehled_o_objednavkach_verejnych_sluzeb/). If most income from these signed contracts flows into the dominant regional carrier Czech Railways, it is expected that over the period of 2009 - 2019 they will receive more than 80 billion Czech crowns on their account (approx. 3.2 billion euros). Czech Railways have promised to all regions that during this period they will improve the quality of the current train fleet by investing some of this money into their trains. However, these ten-year contracts entered into by the regions and Czech Railways can be considered negatively as they are in the principle against the liberalization ethics of the EU transport policy, and they also enforce the already strong position of the dominant Czech Railways carrier on the account of others. In addition, signing these contracts contradicts the intentions of the Bavarian $B E G$ discussed above, which propose that tenders be an important tool for making public rail transport more effective and inviting to passengers.

The comparison of Prague, Brno and Ostrava regional rail transport structure with those in German cities leads to a conclusion that there is less pressure in the Czech Republic for competition when selecting transport carriers. Other conclusions are that in the Czech Republic:

- it is harder to coordinate transport service plans with needed rail transport infrastructure changes than it is in Germany. While both the Bavarian $B E G$ and the Saxon transport association (Verkehrsverbund) Oberelbe have jurisdiction over the infrastructure, Czech regions, as the transport service orderer and organizer, do not. Any infrastructure changes must be planned and coordinated with $S Z \check{Z} D C$, where the infrastructure manager does not take the regional rail transport needs much into 
consideration. The separation of urban and suburban transport when no tracks were added in the recent railway corridor modernisation in Prague, Brno and Ostrava hinterlands, which eventually was not realized, was the best example thereof. The addition of a third track in the short stretch of Prague-Libeñ - Prague-Béchovice, and the creation of the so called 'New Connection' in Prague were the only exceptions.

- less money is invested into the railway infrastructure development or modernization than in Germany; a detailed comparison of statistical data related to the whole German and Czech networks is available in Table 4. Particularly the roughly two times lower level of investments recalculated per $100 \mathrm{~km}$ of railway lines is a highly important factor as it could be seen as one of the crucial reasons for insufficient infrastructure in Czech metropolises, making it hard to effectively separate urban, suburban, long-distance passenger and freight trains.

- in the cities of Prague, Brno and Ostrava and their hinterlands, the regions are developing integrated transport systems with the rail transport serving as a Spine Transport System. In comparison to German cities, however, they are quite problematic (except maybe for Brno and its South Moravian Integrated Public Transport System). Particularly in Prague and its hinterlands, the situation is complicated with the city centre being administratively separated from the rest of its hinterland and run by two, not quite compatible, transport systems PID (Prague Integrated Transport) and SID (Central Bohemian Integrated Transport). As a result, there is only a partial integration, or absolute non-integration, of trains on some routes in Prague hinterlands into the PID.

Table 4 Investments made into the Rail Transport Infrastructure Development or Modernization in Germany and in the Czech Republic between 2005 and 2013 (in millions of EUR)

\begin{tabular}{|l|r|r|r|r|r|r|r|r|r|r|r|}
\hline & 2005 & 2006 & 2007 & 2008 & 2009 & 2010 & 2011 & 2012 & 2013 \\
\hline Germany & 4,016 & 4,402 & 4,423 & 4,621 & 4,609 & 4,970 & 5,128 & 5,012 & 5,303 \\
\hline total & 11.7 & 12.9 & 13.0 & 13.7 & 13.7 & 14.8 & 15.4 & 15.0 & 15.9 \\
\hline per 100 km of railway lines & 0.49 & 0.53 & 0.54 & 0.56 & 0.56 & 0.61 & 0.63 & 0.62 & 0.66 \\
\hline per 10 000 of people & 535 & 511 & 610 & 885 & 733 & 571 & 441 & 367 & $\mathrm{~N} / \mathrm{A}$ \\
\hline Czech Republic & 5.6 & 5.4 & 6.4 & 9.3 & 7.7 & 6.0 & 4.7 & 3.9 & $\mathrm{~N} / \mathrm{A}$ \\
\hline total & 0.52 & 0.50 & 0.59 & 0.85 & 0.70 & 0.54 & 0.42 & 0.35 & $\mathrm{~N} / \mathrm{A}$ \\
\hline per 100 km of railway lines
\end{tabular}

Note: recalculation of the sums in Czech Crowns to EUR was done according to the exchange rate published by the Czech National Bank on $12^{\text {th }}$ August 2013

Sources: Kvizda et al. (2013, p. 92); DB Netz AG (2005, 2006, 2007, 2008, 2009, 2010, 2011, 2012 and 2013); http://www.czso.cz

http://epp.eurostat.ec.europa.eu/portal/page/portal/eurostat/home/

- less is invested into the operation of the regional rail transport systems than in Germany. Table 5 shows an easy comparison of Bavaria and Saxony with corresponding regions of the Czech Republic. When recalculated into a one train 
kilometre, or one resident, the invested amount of money in the Czech Republic into the regional rail transport system is two times lower, and in some case even more than two times lower than in Germany. The consequences could be both the lower train frequency and the age and worse quality of the train fleet that Czech Railways run the urban and suburban rail transport with.

Table 5 Investments into the Operation of the Regional Rail Transport Systems in Selected Regions in Germany and in the Czech Republic in 2013

\begin{tabular}{|c|c|c|c|c|c|}
\hline \multirow{3}{*}{ City } & \multicolumn{2}{|c|}{ Regional rail transport } & \multicolumn{3}{|c|}{$\begin{array}{l}\text { Finance invested into the operation } \\
\text { of the regional rail transport system }\end{array}$} \\
\hline & \multirow{2}{*}{ ordering body } & \multirow{2}{*}{ Coordinator } & total & per 1 train $\mathrm{km}$ & per capita \\
\hline & & & mio. EUR & EUR & EUR \\
\hline $\begin{array}{l}\text { Munich, } \\
\text { berg }\end{array}$ & Bavaria & BEG & 924.8 & 7.9 & 74 \\
\hline Dresden & Saxony & $\begin{array}{|ll|}\text { transport } & \text { association } \\
\text { Oberelbe } & \\
\end{array}$ & 91.4 & 11.0 & 76 \\
\hline & Prague Region & ROPID & 26.9 & 5.9 & 22 \\
\hline Prague & Bohemian & $\begin{array}{l}\text { ROPID, } \\
\text { Central } \\
\text { Region }\end{array}$ & 55.9 & 3.9 & 44 \\
\hline Brno & South Moravian Region & KORDIS & 33.2 & 3.7 & 28 \\
\hline Ostrava & $\begin{array}{l}\text { Moravian-Silesian } \\
\text { Region }\end{array}$ & ODIS & 23.6 & 4.6 & 27 \\
\hline
\end{tabular}

Note: recalculation of the sums in Czech Crowns to EUR was done according to the exchange rate published by the Czech National Bank on $12^{\text {th }}$ August 2013

Sources: http://www.mdcr.cz/cs/verejna-doprava/prehled_o_ objednavkach_verejnych_sluzeb/; http://beg.bahnland-bayern.de/; $\quad$ http://www.vvo-online.de/; $\quad$ http://www.cnb.cz/;

http://www.czso.cz

\section{Rail Transport Comparison in Munich, Prague, Dresden, Nuremberg, Brno and Ostrava}

In comparison with the Czech transport service, rail transport services in the selected German metropolitan regions run relatively often as they have high train frequencies.

There is a dense urban and suburban rail transport network in Munich that serves mainly large settlements within its densely populated area. As in other big European cities, the urban and suburban rail transport works on the principle of "go-through" the city centre line (Lejčar, 2009). In the busiest location in Munich centre on the west-eastbound route (between Pasing, Hauptbahnhof and Ostbahnhof stops), there are seven rail tracks on which 500 trains are run in 24 hours. This volume of trains well exceeds the volume on any train route in the Czech Republic. The west-east-bound line mentioned above is the hub for the majority of radial routes going to remote suburbs, when S-Bahn city lines operate at regular intervals from 10 to 40 minutes. The S-Bahn line connects to a regional rail transport system that sometimes runs parallel to the city line and that increases the stop frequency of some stops even more. Figure 2 clearly shows the busiest radial corridor, i.e. the north-bound Munich route which has 100-200 trains going 
through in 24 hours through stretches Munich - Freising and Munich - Munich Airport. The train frequencies of other train routes are lower, however, such a train volume is still much higher than the train volume on any urban or suburban routes in the Czech Republic, including routes within Prague hinterlands.

The three train stations on the main "go-through" city line (train stations Pasing, Hauptbahnhof and Ostbahnhof) mentioned above are the main train interchange hubs, connecting the S-Bahn system with the regional and long-distance lines. The urban and suburban rail transport system connects to both the city transport and also the urban and suburban bus transport. The park\&ride facilities are basically provided at all train stations of the urban and suburban S-Bahn zone. The parking capacity is appropriate to the demand and is usually from 20 - 300 parking spaces (maximum of 1,276 parking spaces at the Fröttmaning station; stations Freising and Grafing Bahnhof also provide almost a thousand parking places, see http://www.mvv-muenchen.de/fileadmin/media/Dateien/ plaene/pdf/Park___Ride__2013.pdf).

Munich's good urban and suburban rail transport infrastructure is a very significant factor enabling the above-mentioned high train frequency in the Munich hub. In comparison to the Czech Republic, Munich has the aforementioned seven-track rail going through Pasing - Hauptbahnhof - Ostbahnhof section, and also other busy corridors have four-track rail sections enabling better separation of urban, suburban, regional, long-distance passenger and freight transport. Four-track rail routes within Munich hinterlands are for example Munich - Augsburg line (west-bound), Ingolstadt (northbound) and Tutzing (south-bound), majority of other routes have two-track rails and only branch lines, side routes or end sections have a single-track rail.

Over the past years, the high quality urban and suburban rail transport system in Munich city and its hinterlands caused a transport demand increase. The $25 \%$ increase in the Munich S-Bahn performance, measured in passenger-kilometres during 1996-2009, is very persuasive evidence (http://beg.bahnland-bayern.de/).

Although the network route density within Prague hinterlands is very similar to that of Munich, the Prague urban and suburban rail transport system does not offer the same train frequency as Munich. The train frequency in Prague and its vicinity is much lower than in Munich. Due to several parallel routes meeting up in Prague centre, the train frequency is $100-200$. However, the train frequency on radial urban and suburban corridors is only 20-80 trains in 24 hours. The highest train volume is on the Prague - Kolín stretch, and also on a short Beroun-bound stretch ending in Prague-Radotín. One of the possible reasons for such a relatively high train frequency on the Prague - Kolin stretch is that this stretch is on the main national corridor from Prague to Moravia. Another reason could be its better infrastructure as there are three parallel rail tracks on the Prague-Libě̌ - Poříčany stretch. All other routes going from Prague have two parallel rail tracks at the most and some urban and suburban routes only have a single-track rail (for example the lines Prague - Kladno, Prague - Neratovice and Prague - Vrané nad Vlta$v o u)$. Such a system does not allow separation of urban, suburban, long-distance passenger and freight transport, unlike in Munich. 
Figure 2 Munich - Urban and Suburban Rail Transport System

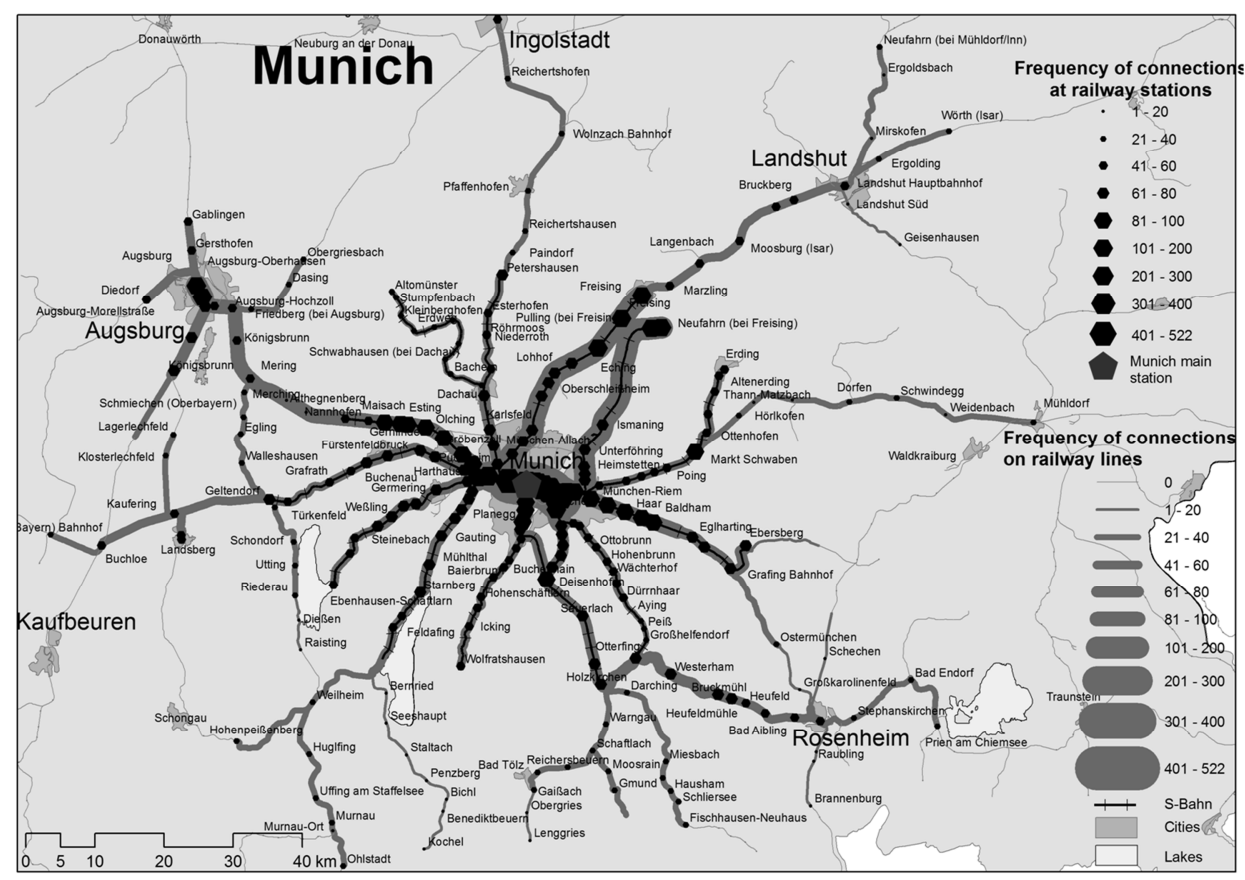

Source: http://persoenlicherfahrplan.bahn.de; http://www.bahn.de

In comparison to the Munich urban and suburban rail transport system, Prague urban and suburban trains lack the speed. Within the travelling time limit of 60 minutes, Prague trains travelled only 40-50 km whereas Munich trains travelled 60-80 km.

In Prague and its vicinity, rail transport is integrated into the so-called Prague Integrated Transport System (IDS PID) and together with the underground and tram system creates a spine transport system. At important terminals and selected stops, this spine system then connects to the bus transport system. Main Train Station, Masaryk Train Station, Smíchov, Vršovice, Libeř, Holešovice and Vysočany train stations are the most important rail transport terminals within the Prague area. The whole IDS PID system runs under the same transport and fare policies, and the timetables of all connecting lines are coordinated. As in Munich, Prague also provides park\&ride facilities, allowing to combine car and train journey. However, the number of parking facilities is, unlike in $\mathrm{Mu}-$ nich, very low. According to the web site http://www.ropid.cz/, parking facilities are provided only in the following train stations Prague-Běchovice, Prague-Holešovice and Prague-Radotín. 
Figure 3 Prague - Urban and Suburban Rail Transport System

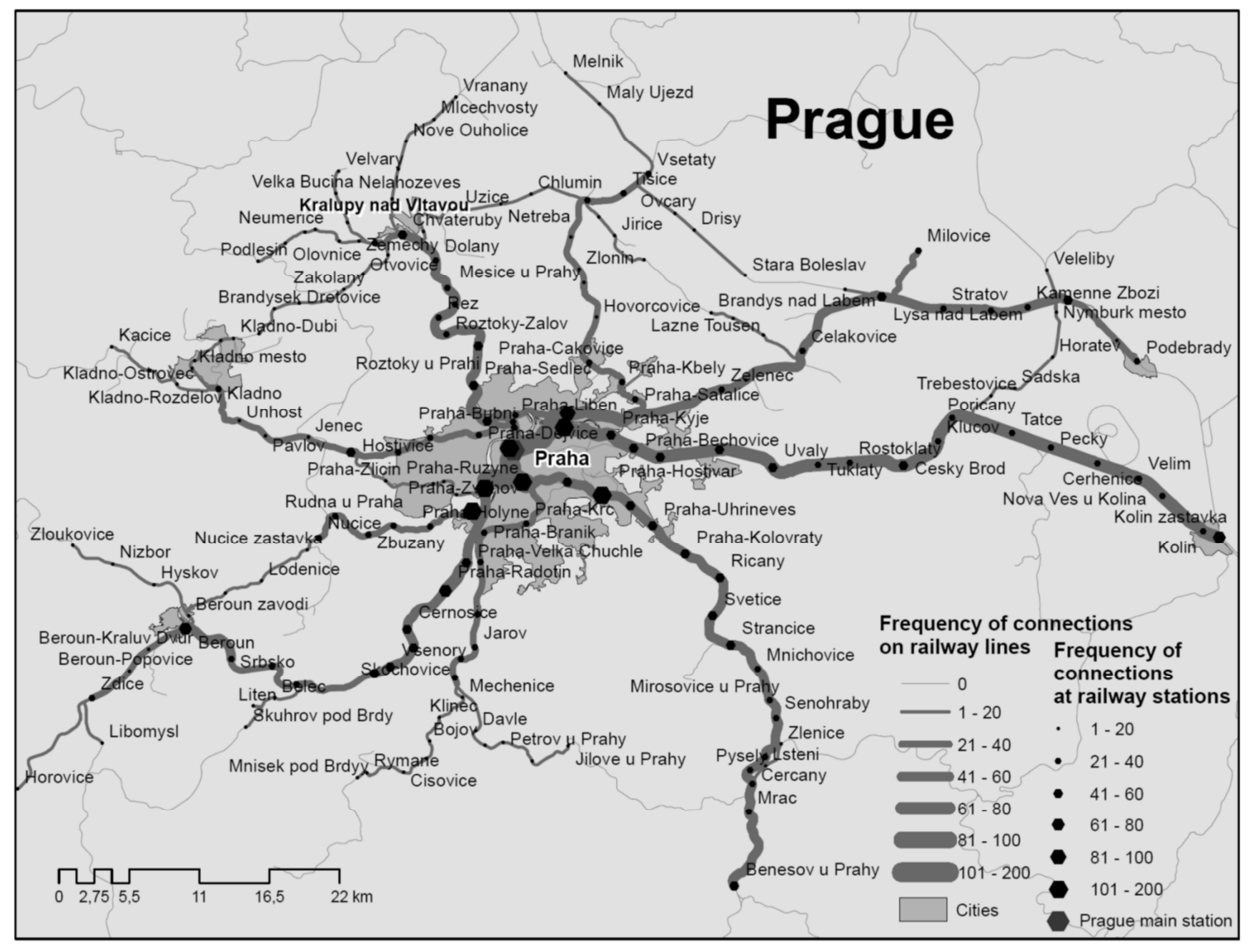

Source: http://www.jizdnirady.cz

Finding information about passengers using the rail transport system in Prague and its vicinity was very hard and its form did not allow direct and easy comparison to the Munich information. Several years old data, provided by Marada (2006, p.73) and showing daily amount of passengers in urban and suburban trains going from Prague and back on selected radial routes during 2004, are as follows:

- Prague - Kolín: 8,208 passengers,

- Prague - Beroun: 4,863 passengers,

- Prague - Benešov: 3,801 passengers.

- Prague - Kralupy nad Vltavou: 2,836 passengers,

- Prague - Lysá nad Labem: 2,769 passengers,

- According to the source used, the numbers mentioned above were valid in 2004, and increase every year,

- the newest rail transport performance information in the IDS PID system is shown on the official operator web site http://www.ropid.cz/ and also in Procházka (2009). 
Unfortunately, none of them show the number of passengers using the rail transport on individual line sections.

In Nuremberg, there are three main directions of their urban and suburban rail transport system and geographically they are, to a certain extent, matching the four existing lines of the S-Bahn system. At all these main routes, the time interval is half an hour and in peak hours the intervals shorten. Side routes have one-hour intervals and off-peak even two-hour intervals. On the main routes going from Nuremberg towards Forchheim and Schwabach, the train frequency is 61 to 80 trains per day. On other radial routes, the train frequency is 41 to 60 trains. At some stops on the studied routes, the train frequency is increased also by regional and long-distance trains stopping there. It is interesting that the number of trains operating in Nuremberg hinterlands is comparable to the number of trains operating in Prague. That clearly illustrates the difference in the number of urban and suburban trains running in Germany and in the Czech Republic as both Nuremberg population and number of jobs do not reach even half of those in Prague. However, the population size of the Nuremberg metropolitan region is similar to that of Prague (see Tables 2 and 3 for details).

As in Munich, Nuremberg also has a good urban and suburban rail transport system infrastructure - in the city centre itself, there are over 13 tracks and the two busiest south-bound and southeast-bound routes have, just before their branching, five tracks (i.e. from Nuremberg to Roth, and to Feucht). Routes in other main directions towards Würzburg, Bamberg, Regensburg, Ingolstadt, Treuchtlingen and Ansbach have two tracks and only remaining side routes have single-track lines.

The urban and suburban rail transport system in Dresden has a lower train frequency than that in Nuremberg which has a comparable population of the core city. Basically, only two corridors are comparable to the main route train frequencies in Nuremberg. The first one is a short north-bound stretch having 81 to 100 trains due to several parallel lines still within the city area. The second one is the southeast-bound stretch along the Elbe River having 61 to 80 trains in the stretch up to Pirna. The other routes have less frequent regular transport and the train frequency does not exceed 40-60 trains per day. As in Munich and Nuremberg, Dresden hinterlands train frequency also consists of a combination of S-Bahn, regional and long-distance trains.

In comparison to Czech cities, Dresden also has quite a good rail transport infrastructure as the busy section on the main corridor along the Elbe River from Dresden to Pirna has four tracks, and even the connecting route from Pirna to the Czech Republic has mostly three tracks. Other routes from Dresden to Meissen, Riesa, Elsterwerda, Bautzen and Freiberg have two tracks. 
Figure 4 Nuremberg - Urban and Suburban Rail Transport System

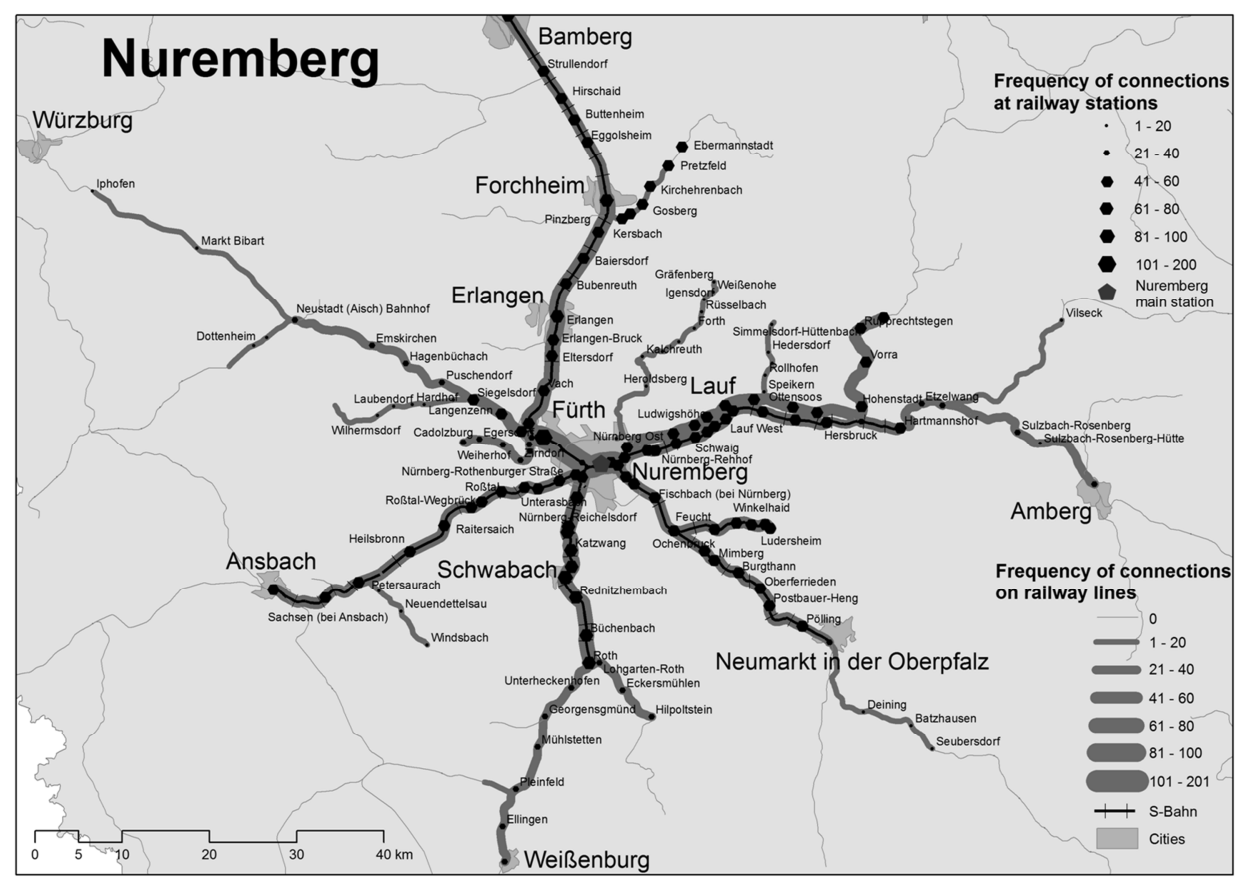

Source: http://persoenlicherfahrplan.bahn.de; http://www.bahn.de

An interesting question arises whether the differences in the two suburban rail transport systems in Nuremberg and Dresden could be interpreted as the differences left over from the ex-East and ex-West Germany. A different starting position may not be the right answer because after 1989 the German government invested heavily into the East Germany infrastructure (Schliephake, 1999, pp. 324-331; Schliephake, 2001), which resulted in a much better shape compared to the West Germany infrastructure. The answer could perhaps be found in the current lower economic workforce or higher unemployment in the ex-East Germany region. This fact contributes to the unwillingness of local people to commute, which results in lower demand for urban and suburban rail transport and lower use of the existing rail transport. Another important factor affecting ex-East Germany and other post socialistic countries could also consist in a change in mobility behaviour which consists mainly in a shift from using public transport to using cars. To a certain extent, some groups of people in the post socialistic Central and Eastern Europe perceive the car as a high social status symbol or as a symbol of personal success (Urbánková, Ouředníček, 2006, pp. 79 and 82-83; Doležalová, Oư̌edníček, 2006). Last, but not least, there is also a clear difference in the population size of Nuremberg and Dresden metropolitan regions (Table 3). 
Figure 5 Dresden - Urban and Suburban Rail Transport System

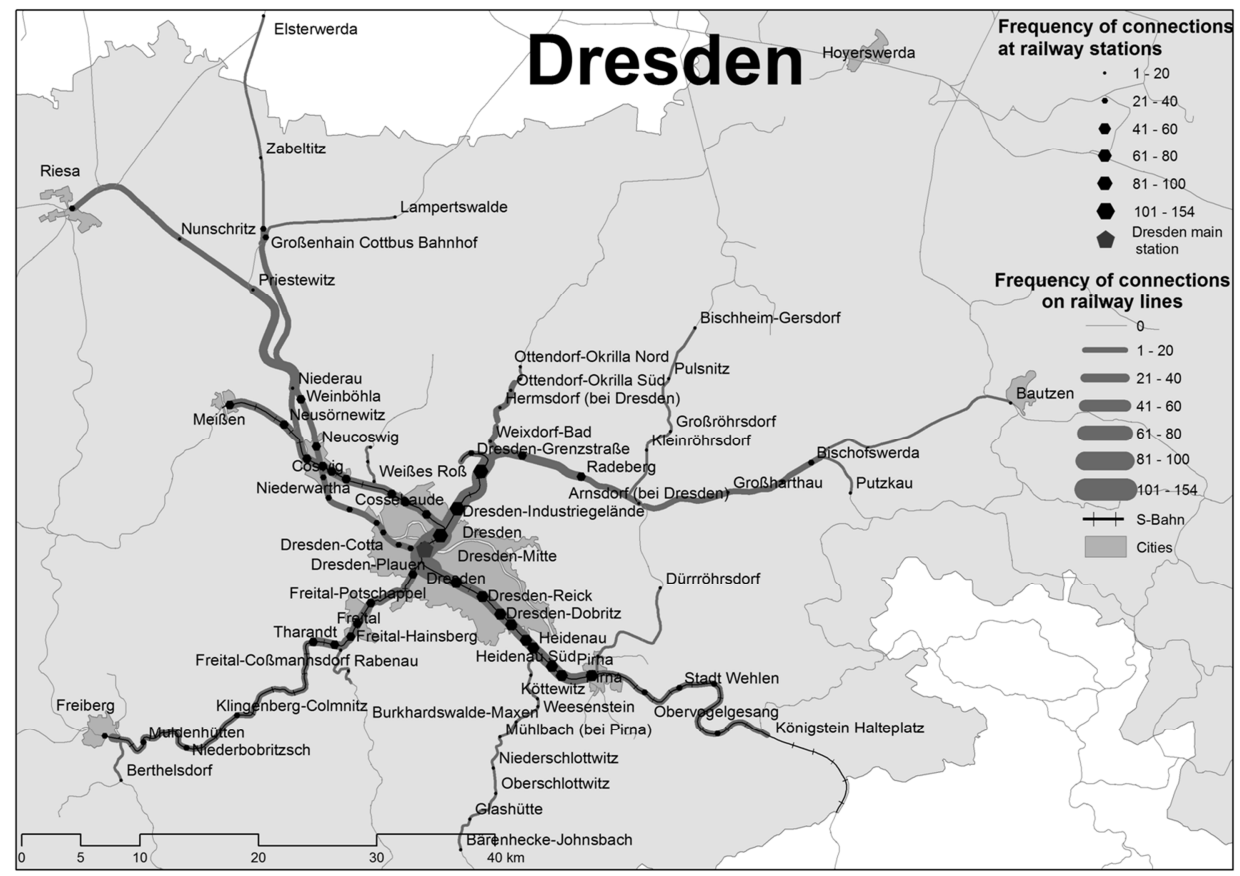

Source: http://persoenlicherfahrplan.bahn.de; http://www.bahn.de

Both main train stations in Nuremberg and Dresden serve as junctions for longdistance, regional and city rail transport and are natural changeover hubs in the entire adjacent regions (Nuremberg for Northern Bavaria region, Dresden for Eastern Saxony region). Their rail transport is fully integrated into the public transport systems sharing a uniformed fare and zone system. Park\&ride facilities with sufficient parking spaces are available at all the peripheral public transport stops in both Nuremberg and Dresden.

Brno, as all of the above-mentioned cities, has a radial rail transport network. Seven railway routes enter Brno centre, all meeting at a key point - Brno Main Train Station. Unlike in Prague and other German cities, all routes have a maximum of two tracks, and an important suburban section from Křenovice horní nádraží, operating in the southeast part of Brno hinterland, is only single-track. The insufficient infrastructure which makes it hard to separate urban, suburban, long-distance passenger and freight transport systems, is worsened by the insufficient capacities of both the main train station itself and the directly adjoining routes. Dukát (2005, p. 12) states: "Another fundamental limiting element of $\check{Z} U B$ (Brno Railway Hub, author's comment) performance is that the main train station has insufficient capacity of only 10 platforms out of which only 6 track are straight through. This number does not add up the number 11, a sum of all the tracks entering the Brno hub. Big European train stations have this ratio of incoming and total amount of track from 1:2 to 1:5. Just for your information, according to this maybe strongly misleading ratio, Brno main train station should have a minimum of 22 plat- 
forms with tracks, or approx. 11 island platforms. Nuremberg, a slightly bigger city than Brno, has such amount of platforms (sic, author's comment). In the Deutsche Bahn $(D B)$ network it plays a similar role as Brno and the traffic organisation in Nuremberg station is in principle the same. Zurich in Switzerland that has the same area size as Brno has 26 platforms."

In the light of the information mentioned above it is not surprising that the suburban train frequency in the Brno agglomeration is relatively low. The three busiest routes (north-bound Brno - Skalice nad Svitavou stretch, south-bound Brno - Hrušovany u Brna stretch and northwest-bound Brno - Tišnov stretch) have frequencies of 41-60 trains, other routes have 21 to 40 trains. The highest train frequencies can be observed at stations with high category trains stopping there.

\section{Figure 6 Brno - Urban and Suburban Rail Transport System}

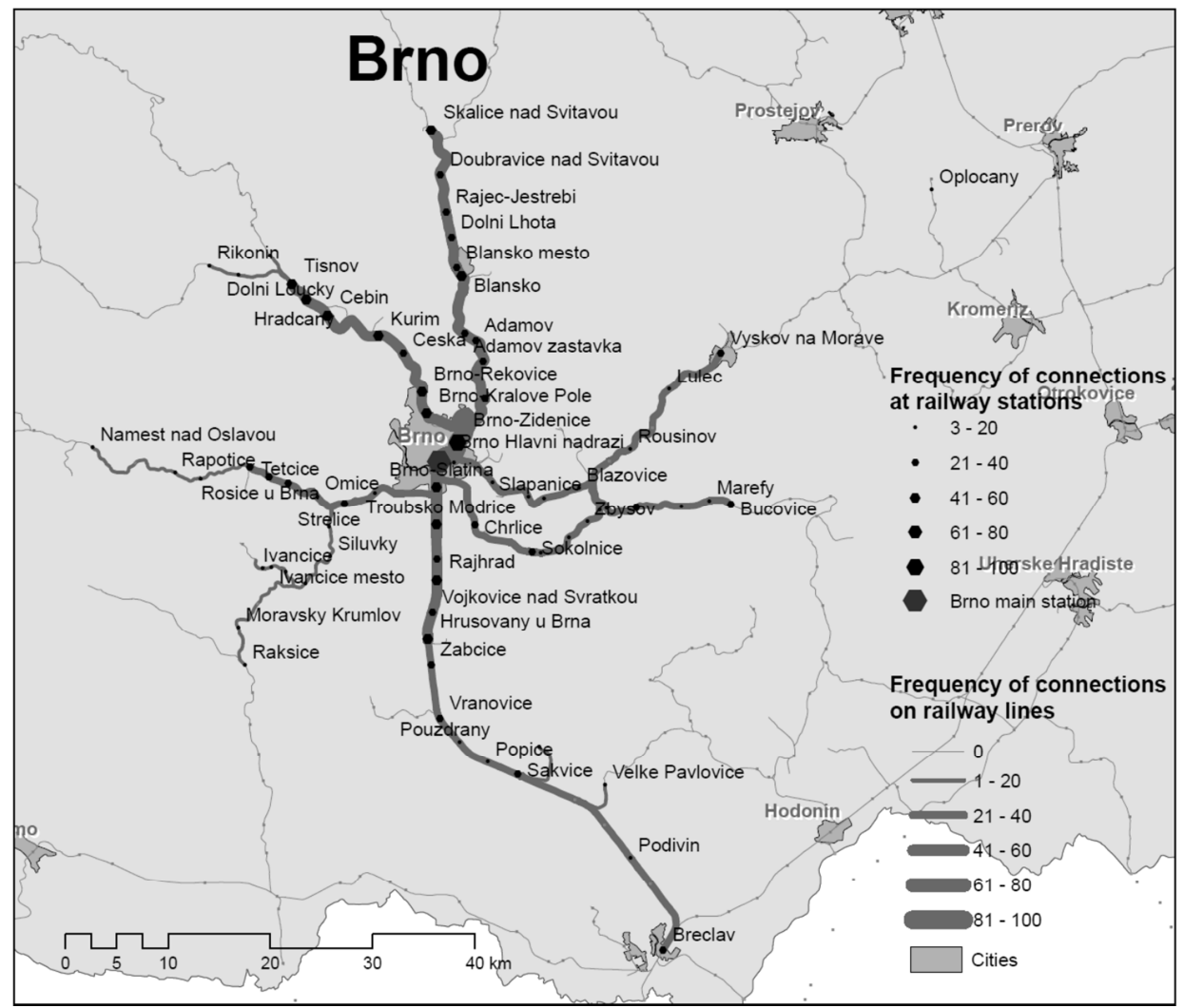

Source: http://www.jizdnirady.cz

Together with other means of transport, rail transport in Brno and its vicinity is incorporated into the South Moravian Integrated Public Transport System (IDS JMK), which is one of the best working systems in the Czech Republic (Mojžíš, Graja, Vančura, 2008, 
pp. 92-94; Seidenglanz, 2007). The amount of passengers in urban and suburban trains has been rising since implementation of the IDS JMK in 2004. In 2003, 18 thousand passengers altogether were using trains from Brno in all directions daily, and it was 25 thousand passengers daily in 2013 (Kordis JMK, 2011, p. 10; Kordis JMK, 2014, p. 71). More than 4 thousand passengers travel on the busiest routes on the stretches of Brno Blansko, Brno - Kuřim, Brno - Střelice and Brno - Rajhrad every day (Novák, 2009). Interconnecting a rail transport and car transport in and around Brno is not currently an issue as none of the local railway stations has park\&ride facilities.

Figure 7 Ostrava - Urban and Suburban Rail Transport System

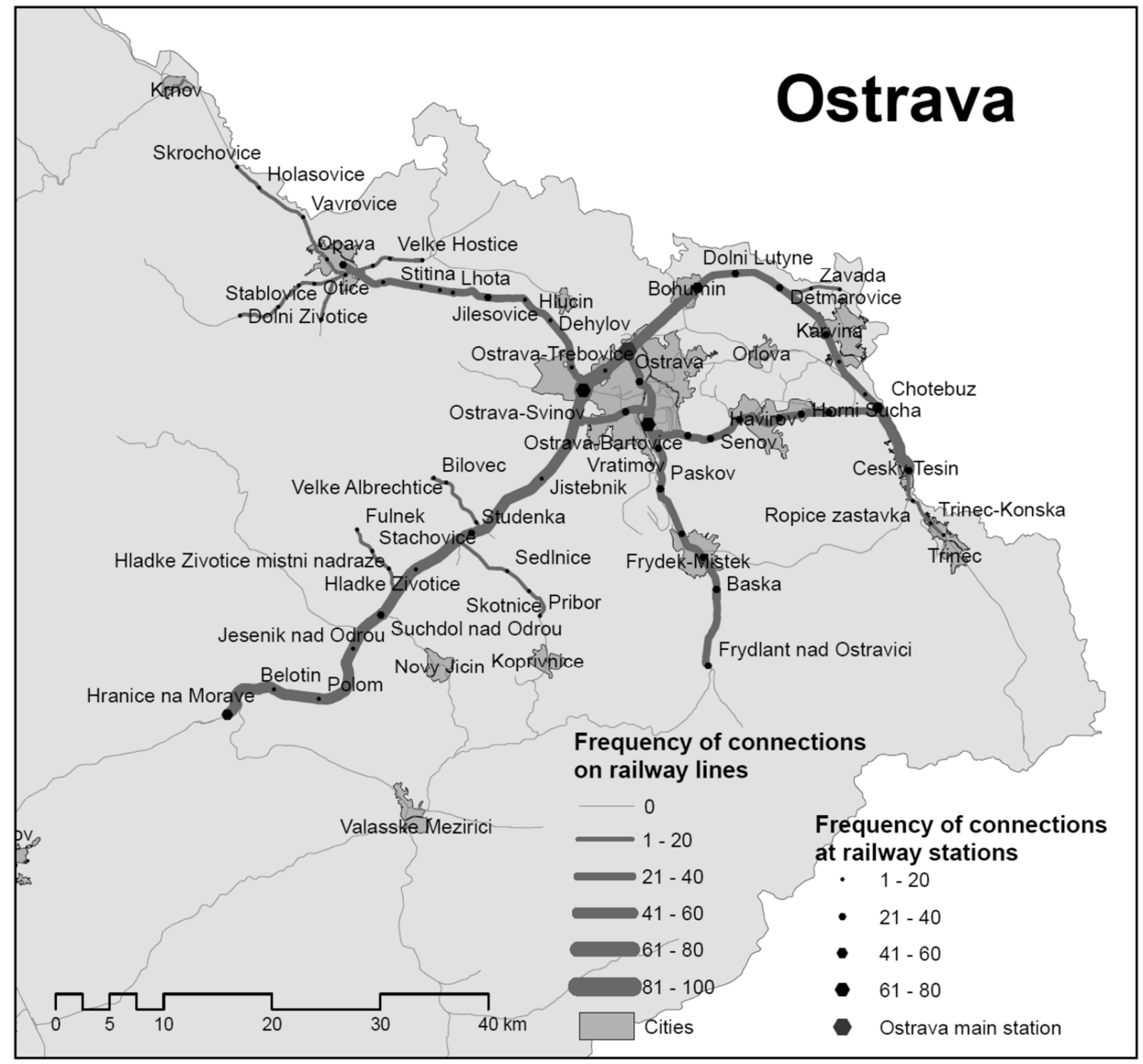

Source: http://www.jizdnirady.cz.

Unlike the aforementioned metropolitan areas, the Ostrava region is a polycentric region because there are other important centres next to the Ostrava - for example, Havírov (population of 77 thousand), Karviná (58 thousand), Frýdek-Místek (58 thousand) or Opava (58 thousand). Despite the patterns of settlement system, the Ostrava 
region does not provide high train frequency services. The highest train frequency (41 to 60 per day) is on the main route in the Hranice na Moravě - Ostrava - Bohumín stretch, however, this frequency is also made up of all high category trains that do not stop at all stops on this route. Other urban and suburban routes have even lower train frequencies, mostly 21 to 40 trains per day. It is possible to travel to Ostrava from other large towns, such as Havírrov, Frýdek-Místek, Karviná or Český Těšín, only by 40 trains per day. For comparison: much smaller towns with much lower population on the main routes in Germany have 60,80 or even 100 trains per day.

As in the case of Brno, Ostrava rail infrastructure, too, is worse than German cities' infrastructure. Most urban and suburban routes have two tracks, however, two important radial routes only have one track - connecting Ostrava with Opava or Frýdek-Místek, both towns with population of around 60 thousand. Unlike Brno, Ostrava Main Train Station has sufficient capacity. Moreover, it does not represent the main hub connecting most urban and suburban trains because there are also three other important stops $S v i$ nov, střed and Kunčice in the Ostrava transport network.

The Ostrava rail system is also incorporated into the Integrated Transport System of the Moravian-Silesian Region, interconnecting trains and fares with other public transport systems. Park\&ride facilities are not developed in the Ostrava region.

Table 6 A Comparison of Train Services in German and Czech Cities - Situation in Large Municipalities Strongly Integrated in the Metropolitan Regions Under Observation

\begin{tabular}{|c|c|c|c|c|c|c|c|}
\hline City & Munich & Nuremberg & Dresden & City & Prague & Brno & Ostrava \\
\hline Large municipality & Freising & Schwabach & $\begin{array}{l}\text { Dresden- } \\
\text { Kloztsche }\end{array}$ & Large municipality & $\begin{array}{l}\text { Prague- } \\
\text { Radotín }\end{array}$ & Adamov & $\begin{array}{l}\text { Frýdek- } \\
\text { Místek }\end{array}$ \\
\hline Population & 45,000 & 39,000 & $\begin{array}{r}\text { part } \\
\text { of Dresden }\end{array}$ & Population & $\begin{array}{r}\text { part } \\
\text { of Prague }\end{array}$ & 5,000 & 58,000 \\
\hline \multicolumn{4}{|l|}{ Number of trains: } & \multicolumn{4}{|l|}{ Number of trains: } \\
\hline total & 92 & 85 & 97 & Total & 66 & 45 & 31 \\
\hline ICE & & & & $\mathrm{EC} / \mathrm{IC} / \mathrm{Ex}$ & & & \\
\hline $\mathrm{EC} / \mathrm{IC}$ & & & & $\mathrm{R}$ & & & \\
\hline NV & 42 & 31 & 58 & Sp & & 3 & \\
\hline S-Bahn & 50 & 54 & 39 & Os & 66 & 42 & 31 \\
\hline \multicolumn{4}{|c|}{ Travel time (in minutes): } & \multicolumn{4}{|c|}{ Travel time (in minutes): } \\
\hline $\begin{array}{l}\text { weighted arithme } \\
\text { tic } \\
\text { mean }\end{array}$ & $35 \mathrm{~min}$. & $16 \mathrm{~min}$. & $14 \mathrm{~min}$. & $\begin{array}{l}\text { weighted arithme- } \\
\text { tic } \\
\text { mean }\end{array}$ & $17 \mathrm{~min}$. & $19 \mathrm{~min}$. & $20 \mathrm{~min}$. \\
\hline ICE & & & & $\mathrm{EC} / \mathrm{IC} / \mathrm{Ex}$ & & & \\
\hline $\mathrm{EC} / \mathrm{IC}$ & & & & $\mathrm{R}$ & & & \\
\hline NV & $26 \mathrm{~min}$ & $12 \mathrm{~min}$. & $14 \mathrm{~min}$. & Sp & & $15 \mathrm{~min}$. & \\
\hline S-Bahn & $43 \mathrm{~min}$. & $19 \mathrm{~min}$ & $15 \mathrm{~min}$ & Os & $17 \mathrm{~min}$ & $19 \mathrm{~min}$. & $20 \mathrm{~min}$. \\
\hline $\begin{array}{l}\text { Distance } \\
\text { (in kilometres): }\end{array}$ & $41 \mathrm{~km}$ & $15 \mathrm{~km}$ & $11 \mathrm{~km}$ & $\begin{array}{l}\text { Distance } \\
\text { (in kilometres): }\end{array}$ & $13 \mathrm{~km}$ & $15 \mathrm{~km}$ & $14 \mathrm{~km}$ \\
\hline \multicolumn{4}{|c|}{ Speed (in kilometres per hour): } & \multicolumn{4}{|c|}{ Speed (in kilometres per hour): } \\
\hline average speed & $70 \mathrm{~km} / \mathrm{h}$ & $56 \mathrm{~km} / \mathrm{h}$ & $47 \mathrm{~km} / \mathrm{h}$ & average speed & $46 \mathrm{~km} / \mathrm{h}$ & $47 \mathrm{~km} / \mathrm{h}$ & $42 \mathrm{~km} / \mathrm{h}$ \\
\hline maximum speed & $160 \mathrm{~km} / \mathrm{h}$ & $200 \mathrm{~km} / \mathrm{h}$ & $120 \mathrm{~km} / \mathrm{h}$ & maximum speed & $100 \mathrm{~km} / \mathrm{h}$ & $80 \mathrm{~km} / \mathrm{h}$ & $80 \mathrm{~km} / \mathrm{h}$ \\
\hline
\end{tabular}


Table 7 A Comparison of Train Services in German and Czech Cities - Situation in Small Municipalities Strongly Integrated in the Metropolitan Regions Under Observation

\begin{tabular}{|c|c|c|c|c|c|c|c|}
\hline City & Munich & Nuremberg & Dresden & City & Prague & Brno & Ostrava \\
\hline Small municipality & Eching & Roßtal & Königstein & Small municipality & Český Brod & Střelice & Jistebník \\
\hline Population & 13,000 & 10,000 & 2,000 & Population & 7,000 & 3,000 & 1,000 \\
\hline \multicolumn{4}{|l|}{ Number of trains: } & \multicolumn{4}{|l|}{ Number of trains: } \\
\hline total & 59 & 53 & 38 & Total & 42 & 41 & 19 \\
\hline ICE & & & & $\mathrm{EC} / \mathrm{C} / \mathrm{Ex}$ & & & \\
\hline $\mathrm{EC} / \mathrm{IC}$ & & & & $\mathrm{R}$ & & & \\
\hline NV & & 7 & & Sp & 3 & 1 & \\
\hline S-Bahn & 59 & 46 & 38 & Os & 39 & 40 & 19 \\
\hline \multicolumn{4}{|c|}{ Travel time (in minutes): } & \multicolumn{4}{|c|}{ Travel time (in minutes): } \\
\hline $\begin{array}{l}\text { weighted arithme- } \\
\text { tic } \\
\text { mean }\end{array}$ & $29 \mathrm{~min}$. & $17 \mathrm{~min}$. & $40 \mathrm{~min}$ & $\begin{array}{l}\text { weighted arithme- } \\
\text { tic } \\
\text { mean }\end{array}$ & $38 \mathrm{~min}$. & $17 \mathrm{~min}$. & $8 \mathrm{~min}$. \\
\hline ICE & & & & $\mathrm{EC} / \mathrm{IC} / \mathrm{Ex}$ & & & \\
\hline$E C / I C$ & & & & $\mathrm{R}$ & & & \\
\hline NV & & $14 \mathrm{~min}$. & & Sp & $31 \mathrm{~min}$. & $17 \mathrm{~min}$. & \\
\hline S-Bahn & $29 \mathrm{~min}$. & $18 \mathrm{~min}$ & $40 \mathrm{~min}$. & Os & $38 \mathrm{~min}$. & $17 \mathrm{~min}$. & $8 \mathrm{~min}$. \\
\hline $\begin{array}{l}\text { Distance } \\
\text { (in kilometres): }\end{array}$ & $27 \mathrm{~km}$ & $15 \mathrm{~km}$ & $35 \mathrm{~km}$ & $\begin{array}{l}\text { Distance } \\
\text { (in kilometres): }\end{array}$ & $34 \mathrm{~km}$ & $13 \mathrm{~km}$ & $9 \mathrm{~km}$ \\
\hline \multicolumn{4}{|c|}{ Speed (in kilometres per hour): } & \multicolumn{4}{|c|}{ Speed (in kilometres per hour): } \\
\hline average speed & $56 \mathrm{~km} / \mathrm{h}$ & $53 \mathrm{~km} / \mathrm{h}$ & $53 \mathrm{~km} / \mathrm{h}$ & average speed & $54 \mathrm{~km} / \mathrm{h}$ & $46 \mathrm{~km} / \mathrm{h}$ & $68 \mathrm{~km} / \mathrm{h}$ \\
\hline maximum speed & $160 \mathrm{~km} / \mathrm{h}$ & $160 \mathrm{~km} / \mathrm{h}$ & $160 \mathrm{~km} / \mathrm{h}$ & maximum speed & $140 \mathrm{~km} / \mathrm{h}$ & $100 \mathrm{~km} / \mathrm{h}$ & $160 \mathrm{~km} / \mathrm{h}$ \\
\hline
\end{tabular}

Source: http://persoenlicherfahrplan.bahn.de; http://www.bahn.de; http://www.jizdnirady.cz

All the statements above about higher train frequencies and faster urban and suburban trains in the German cities of Munich, Nuremberg and Dresden compared to the Czech cities of Prague, Brno and Ostrava are well documented in Tables 6, 7, and 8. These tables show specific data from selected stations in their hinterlands. Moreover, the tables depict the situation in three location types - in large (i) and small (ii) municipalities strongly integrated in the metropolitan regions under observation and in large towns (iii) situated in a considerable distance from the studied cities. In order to make the individual locations in tables comparable, only the busiest rail transport radial routes were selected. 
Table 8 Comparison of Train Services in German and Czech Cities - Situation in Large Towns Situated in a Considerable Distance from Core Cities

\begin{tabular}{|c|c|c|c|c|c|c|c|}
\hline City & Munich & Nuremberg & Dresden & City & Prague & Brno & Ostrava \\
\hline Large town & Augsburg & Bamberg & Pirna & Large town & Kolín & Břeclav & Opava \\
\hline Population & 270,000 & 70,000 & 38,000 & Population & 31,000 & 25,000 & 58,000 \\
\hline \multicolumn{4}{|l|}{ Number of trains: } & \multicolumn{4}{|l|}{ Number of trains: } \\
\hline total & 91 & 35 & 67 & Total & 86 & 28 & 37 \\
\hline ICE & 33 & 9 & & $\mathrm{EC} / \mathrm{IC} / \mathrm{Ex}$ & 24 & 15 & \\
\hline $\mathrm{EC} / \mathrm{IC}$ & 16 & 1 & & $\mathrm{R}$ & 30 & 9 & 7 \\
\hline NV & 42 & 25 & & $\mathrm{Sp}$ & 2 & 4 & 10 \\
\hline S-Bahn & & & 67 & Os & 30 & & 20 \\
\hline \multicolumn{4}{|c|}{ Travel time (in minutes): } & \multicolumn{4}{|c|}{ Travel time (in minutes): } \\
\hline $\begin{array}{l}\text { weighted arithme- } \\
\text { tic } \\
\text { mean } \\
\end{array}$ & $37 \mathrm{~min}$. & $43 \mathrm{~min}$. & $21 \mathrm{~min}$ & $\begin{array}{l}\text { weighted arithme- } \\
\text { tic } \\
\text { mean }\end{array}$ & $55 \mathrm{~min}$. & $38 \mathrm{~min}$. & $29 \mathrm{~min}$. \\
\hline ICE & $32 \mathrm{~min}$. & $39 \mathrm{~min}$. & & $\mathrm{EC} / \mathrm{IC} / \mathrm{Ex}$ & $47 \mathrm{~min}$. & $31 \mathrm{~min}$. & \\
\hline$E C / I C$ & $31 \mathrm{~min}$ & $40 \mathrm{~min}$. & & $\mathrm{R}$ & $47 \mathrm{~min}$. & $45 \mathrm{~min}$. & $21 \mathrm{~min}$. \\
\hline NV & $44 \mathrm{~min}$. & $45 \mathrm{~min}$ & & Sp & $58 \mathrm{~min}$. & $46 \mathrm{~min}$. & $26 \mathrm{~min}$. \\
\hline S-Bahn & & & $21 \mathrm{~min}$. & Os & $70 \mathrm{~min}$. & & $33 \mathrm{~min}$. \\
\hline $\begin{array}{l}\text { Distance } \\
\text { (in kilometres): }\end{array}$ & $62 \mathrm{~km}$ & $62 \mathrm{~km}$ & $17 \mathrm{~km}$ & $\begin{array}{l}\text { Distance } \\
\text { (in kilometres): }\end{array}$ & $62 \mathrm{~km}$ & $59 \mathrm{~km}$ & $28 \mathrm{~km}$ \\
\hline \multicolumn{4}{|c|}{ Speed (in kilometres per hour): } & \multicolumn{4}{|c|}{ Speed (in kilometres per hour): } \\
\hline average speed & $101 \mathrm{~km} / \mathrm{h}$ & $87 \mathrm{~km} / \mathrm{h}$ & $49 \mathrm{~km} / \mathrm{h}$ & average speed & $68 \mathrm{~km} / \mathrm{h}$ & $93 \mathrm{~km} / \mathrm{h}$ & $58 \mathrm{~km} / \mathrm{h}$ \\
\hline maximum speed & $230 \mathrm{~km} / \mathrm{h}$ & $160 \mathrm{~km} / \mathrm{h}$ & $120 \mathrm{~km} / \mathrm{h}$ & maximum speed & $160 \mathrm{~km} / \mathrm{h}$ & $160 \mathrm{~km} / \mathrm{h}$ & $100 \mathrm{~km} / \mathrm{h}$ \\
\hline
\end{tabular}

Source: http://persoenlicherfahrplan.bahn.de; http://www.bahn.de; http://www.jizdnirady.cz.

\section{Conclusion - Liberalization Benefit for Urban and Suburban Rail Transport}

Despite the relatively low usage in the current EU transport market, passenger rail transport remains to play an important role in the urban and suburban transport of large cities hinterlands. Within their transport system, the rail transport can serve as a spine system connecting other feeder routes in the hinterlands. As the rail transport is separated from other means of city transport, it offers a relatively uncomplicated and fast access to city centres.

The empirical material presented in this article shows that the city and suburban rail transport is quite good in the metropolitan regions of both selected German (Munich, Nuremberg and Dresden) and Czech cities (Prague, Brno and Ostrava). However, it is necessary to emphasize that German urban and suburban rail transport provides a higher train frequency even when compared to equally or to similarly populated core cities of metropolitan regions in the Czech Republic. Also, when comparing equally populated settlements within similar distance from the tested cities, urban and suburban trains in Germany were faster and much more interconnected with a car transport thanks to park\& ride facilities.

In addition to the positive parameters of the German urban and suburban rail transport in Munich, Nuremberg and Dresden, German rail transport sector is in a higher stage of 
liberalization than in Prague, Brno and Ostrava. The following business plans can be used as an example where a local Bavarian transport coordinator Bayerische Eisenbahngesellschaft plans that half of their rail transport services will be subcontracted through tenders by 2015, and all of the rail transport services will be subcontracted by 2023. In the Czech Republic regions, on the other hand, not much will probably change by 2019 as all regions signed ten-year contracts with one directly awarded operator Czech Railways. Moreover, these contracts are extendable by five years, in which case the contracts would expire in 2024.

Taking the above information into consideration, another question arises whether liberalization, or the level of rail transport market openness, is a key marker for determining level of urban and suburban rail transport in Germany and in the Czech Republic. Based on the relatively detailed analyses of operation background in both studied countries and of current urban and suburban rail transport state, we came to the conclusion that liberalization apparently is not the key marker. The resulting quality of rail transport services in metropolitan regions is in both Germany and the Czech Republic primarily created by the following:

- an obviously important role is played by the joint activity of the ordering bodies and the train service coordinators, both setting and developing the particular transport concept. The level of their cooperation and their professional skills are key factors influencing the shape of urban and suburban rail transport systems in their areas (e.g. the succesfull activities of BEG in Bavaria or KORDIS JMK, the coordinator of IDS JMK in Brno region);

- the developing urban and suburban rail transport systems have to be adapted as much as possible to geographical patterns and conditions of the selected metropolitan region. Thus the population size of the core city and of its whole hinterland, the spatial distribution of cities and settlements within it, the population density and many other factors like the general mobility or the income level are certainly some of the key aspects that have to be taken into consideration when producing an appropriate transport concept (e.g. the population size of Munich metropolitan region support higher train frequencies in comparison with the Prague one);

- the ideal form of the transport concept designed by the professional activity of the ordering bodies and the train services coordinators has to be adjusted to existing constraints. It is obvious that available financial sources for the operation of train services and for infrastructure building on one hand, and the state of the railway infrastructure in the metropolitan region on the other are the most important of them. Therefore, these conditions sometimes completely disable the implementation of the desired transport concept (e.g. it is impossible for the railway infrastructure in Prague, Brno and Ostrava regions to separate different types of trains, which decreases the capacity of radial routes to accommodate the high frequency of urban and suburban transport);

- in summary, the factors mentioned above are in our opinion roughly equally important primary aspects differing the level of urban and suburban rail transport 
between Germany and the Czech Republic. They all act in reciprocal cooperation and thus strengthen one another in their transport consequences.

The role of the railway environment liberalization/openness is a bit different in the urban and suburban transport system, however, its importance cannot be totally overlooked as it is a supporting tool for the ordering bodies and the coordinators to strongly affect the design and price of ordered transport services. We believe that thanks to competition between the carriers, brought up regularly by tenderings, it is possible to choose the most effective and purposeful transport service providers. Also based on geographical knowledge, knowledge of infrastructure environment and their financial limits, the ordering party can select the best transport service providers within the required conditions. Competition between tendering carriers can be also understood as a tool for the carrier's stimulation and pro-activity. The above ideas, in principle, describe the aims that are expected from the tenderings in Bavaria by their railway coordinator $B E G$, i.e. to get a relatively cheap regional rail transport carrier that offers quality service that is inviting to passengers.

In our opinion, a gradual liberalization of the rail transport sector needs to be taken as a phenomena that has no direct economic, social or environmental impact, and as such will not increase the quality of the urban and suburban transport but will enable the ordering party and the transport coordinator to reach their goals as it stimulates competition between transport service providers on the transport market. If liberalization contributes to better quality and more attractive transport to passengers, it will increase the usage of rail transport in metropolitan regions to the exclusion of car transport, and that will have indirect but important socio-economic impacts. Some impacts on a real-life metropolitan environment could be as follows (e.g. Herbert, Thomas, 1997, pp. 138156):

- Relative decrease in the environmentally less friendly means of transport and consequent decrease of negative environmental impacts generated by traffic.

- Congestion decrease in car transport in cities and their vicinities.

- Accident decrease and transport safety increase.

- Relative decrease in road building and widening projects.

- Partial concentration of transport flows and possible consequent change in residential area preferences.

- Despite all of the changes mentioned above, the current high level of personal mobility in cities and their vicinities could remain as the service quality and high train frequencies will be maintained.

- The above-mentioned indirect socio-economic impacts of the railway sector liberalization are just examples of its possible effects and they could be analysed in another more detailed study. Moreover, the examples specified above are speculative as empiric testing of all the relations between the liberalization sector level, the carrier offers and the indirect socio-economic impacts would require an entirely new study. 
Finally, it is possible to say that compared to Germany, city and suburban rail transport in the Czech Republic shows some quantitative inadequacies. Although railway sector liberalization is not a primary determinant of the existing differences, it seems that increased competition in the transport market, i.e. the option for the region to choose from several carriers offers, could at least partially increase the user-friendliness of rail transport in the Czech environment. The increased demand could then positively affect the offer and some socio-economic impacts would take place and could be monitored.

\section{References}

BECK, A. (2011). Barriers to Entry in Rail Passenger Services: Empirical Evidence for Tendering Procedures in Germany. European Journal of Transport and Infrastructure Research. 11(1), 2011, pp. 20-41.

BRANDT, T. (2006). Liberalisation, privatisation and regulation in the German local public transport sector. Country reports on liberalisation and privatisation processes and forms of regulation. Düsseldorf: Wirtschafts- und Sozialwissenschaftliches Institut in der Hans-Böckler-Stiftung.

BRINKE, J. (1999). Úvod do geografie dopravy. Praha: Univerzita Karlova v Praze nakladatelství Karolinum.

CHARLTON, C., VOWLES, T. (2008). Inter-urban and regional transport. In R. Knowles, J. Shaw, I. Docherty (Eds.), Transport geographies: mobilities, flows and spaces (pp. 120-136). Oxford: Blackwell Publishing.

DOLEŽALOVÁ, G., OUŘEDNÍČEK, M. (2006). Životní styl obyvatel v suburbánní zóně Prahy. In M. Ouředníček (Ed.) Sociální geografie pražského městského regionu (pp. 143-159). Praha: Univerzita Karlova v Praze.

DUKÁT, J. (2005). Co s brněnským železničním uzlem?. Národohospodářský obzor. Roč. V, 4-2005, pp. 6-20.

GIVONI, M. (2006). Development and impact of the modern high-speed train: a review. Transport reviews. 26(5), pp. 593-611. DOI: 10.1080/01441640600589319.

GUTIÉRREZ, J., GARCÍA-PALOMARES, J.C. (2007). New spatial patterns of mobility within the metropolitan area of Madrid: towards more complex and dispersed flow networks. Journal of transport geography. 15 (2007), pp. 18-30. DOI: 10.1016/j.jtrangeo.2006.01.002.

HAMPL, M. (2005). Geografická organizace společnosti v České republice: transformační procesy a jejich obecný kontext. Praha: Univerzita Karlova v Praze.

HERBERT, D.T., THOMAS, C.J. (1997). Cities in space, city as a place. 3rd ed. London: David Fulton Publishers.

HOLVAD, T. (2009). Review of railway policy reforms in Europe. Built Environment. 35(1), pp. 24-42. 
HORŇÁK, M., PŠENKA, T. (2013). Verejná doprava ako indikátor medzisídelných väzieb medzi mestami Slovenska. Geografický časopis. Vol. 65, no. 2 (2013), pp. 119140.

HUNOLD, M., WOLF, Ch. (2013). Competitive procurement design: Evidence from regional passenger railway services in Germany. ZEW Discussion Paper. No. 13-009, pp. 1-22.

IBM Corporation. (2011). Rail Liberalisation Index 2011. Market opening: comparison of the rail markets of the Member States of the European Union, Switzerland and Norway. Brussels: IBM Corporation.

KNOWLES, R.D. (2006). Transport shaping space: differential collapse in time-space. Journal of transport geography. 14 (2006), pp. 407-425. DOI: 10.1016/j.jtrangeo.2006.07.001.

KORDIS JMK. (2011). Integrovaný dopravní systém Jihomoravského kraje - zpráva o vývoji, duben 2011. Brno: Kordis JMK, spol. s r.o.

KORDIS JMK. (2014). 10 let IDS JMK. Brno: Kordis JMK a.s.

KRIŽAN, F., HORŇÁK, M. (2012). Vplyv súkromného prepravcu na verejnú železničnú dopravu: prípadová štúdia spoločnosti Regio JET na Slovensku. In M. Kvizda, Z. Tomeš (Eds.), Konkurence na železnici - budoucnost pro 21. století nebo destrukce sítě? Sborník přispěvků ze semináre Telč 2012 (pp. 22-31). Brno: Masarykova univerzita.

KVIZDA, M. (2010). Impacts of Unbundling on Competitiveness of Railways. Železniční doprava a logistika. Roč. 2010, č. 02, pp. 66-72.

KVIZDA, M., MLSNA, P., NIGRIN, T., SEIDENGLANZ, D., TOMEŠ, Z. (2013). Metodika optimalizace institucionálního prostředív železniční dopravě v České republice. Brno, Praha: Masarykova univerzita, Univerzita Karlova v Praze.

LÄGER, J. (2004). Wettbewerb und Regionalisierung im SPNV - Ein Handbuch. Krefeld: Röhr-Verlag für spezielle Verkehrsliteratur.

LEJČAR, I. (2009). Příměstská železnice - důležitá součást veřejné dopravy. Vybrané př́klady z evropských měst - inspirace pro Prahu. Praha: Ministerstvo dopravy.

MAIER, K., MULÍČEK, O., FRANKE, D. (2010). Vývoj regionalizace a vliv infrastruktur na atraktivitu území České republiky. Urbanismus a územní rozvoj. Roč. XIII, č. 5, pp. 71-81.

MARADA, M. (2006). Dopravní vztahy v Pražském městském regionu. In M. Ouředníček (Ed.) Sociální geografie pražského mèstského regionu (pp. 64-78). Praha: Univerzita Karlova v Praze.

MOFAIR e. V, NETZWERK EUROPÄISCHER EISENBAHNEN e. V. (2013). Wettbewerber-Report Eisenbahn 2013/2014. Berlin.

MOJŽÍŠ, V., GRAJA, M., VANČURA, P. (2008). Integrované dopravní systémy. Praha: powerprint. 
NIGRIN, T. (2014). Open Competition or Discrimination on Tracks? Examples of Anticompetitive Behaviour of the Deutsche Bahn. Review of Economic Perspectives - Národohospodářský prostor. Roč. 14, č. 1, pp. 16-33.

NOVÁK, K. (2009). Železniční doprava - páteř IDS JMK. Retrieved September 19, 2013, from http://www.railvolution.net/czechraildays/2009/odborne-seminare.php.

NOVOTNÝ, V., FRANKE, D., POKORNÁ, I. (2008). A theoretical approach to the computation of functional accessibility. Journal of landscape studies. 1 (2008), pp. 7989.

PROCHÁZKA, P. (2009). Železnice v pražské integrované dopravě. Retrieved September 19, 2013, from http://www.railvolution.net/czechraildays/2009/odborneseminare.php.

PwC. (2013). Liberalisierung im Güter- und Personenverkehr schreitet voran. Retrieved September 25, 2013, from http://www.pwc.de/de/transport-undlogistik/liberalisierung-im-gueter-und-personenverkehr.jhtml.

SCHLIEPHAKE, K. (1999). Reunification of Germany's transport infrastructures projects and achievements. In J. Kitowski (Ed.), Prace Komisji Geografii Komunikacji PTG (pp. 319-334). Warszawa, Rzeszow: Komisja Geografii Komunikacji Polskiego Towarzystwa Geograficznego, Uniwersytet Marii Curie-Skłodowskiej.

SCHLIEPHAKE, K. (2001). Personenverkehr in Deutschland. STANDORT - Zeitschrift für Angewandte Geographie. Heft 1, März 2001, 25. Jahrgang, pp. 19-28.

SCHNELL, M. (2001). Competition for the German regional rail passenger market 5 years after regionalization. Transport Reviews. 22(3), pp. 323-334. DOI: 10.1080/01441640110096607.

SEIDENGLANZ, D. (2006). Železnice v Evropě a evropská dopravní politika. Brno: Masarykova univerzita.

SEIDENGLANZ, D. (2007). Dopravní charakteristiky venkovského prostoru. Disertační práce. Masarykova univerzita, Př́rodovědecká fakulta.

SEIDENGLANZ, D. (2008). Geografie dopravy. In V. Toušek, J. Kunc, J. Vystoupil (Eds.), Ekonomická a sociální geografie (pp. 231-269). Plzeň: Aleš Čeněk.

TAKAGI, R. (2005). High-speed railways: the last 10 years. Japan railway \& transport review. 40 (2005), pp. 4-7.

TOMEŠ, Z. (2009). Monopol a konkurence na železnici. Scientia et Societas. 4/09, pp. 139-149.

TOMEŠ, Z. (2011). Competition Limits in Railway Transport. Ekonomický časopis/Journal of Economics. Roč. 59/2011, č. 2, pp. 194-203.

TURTON, B., KNOWLES, R. (1998). Urban transport problems and solutions. In B.S. Hoyle, R.D. Knowles (Eds.), Modern transport geography (pp. 135-157). Chichester: Wiley. 
URBÁNKOVÁ, J., OUŘEDNÍČEK, M. (2006). Vliv suburbanizace na dopravu v Pražském městském regionu. In M. Ouředníček (Ed.) Sociální geografie pražského městského regionu (pp. 79-95). Praha: Univerzita Karlova v Praze.

\section{Statistical data and other sources}

DB Netz AG (2005). Geschäftsbericht 2005. Frankfurt am Main.

DB Netz AG (2006). Geschäftsbericht 2006. Frankfurt am Main.

DB Netz AG (2007). Geschäftsbericht 2007. Frankfurt am Main.

DB Netz AG (2008). Geschäftsbericht 2008. Frankfurt am Main.

DB Netz AG (2009). Geschäftsbericht 2009. Frankfurt am Main.

DB Netz AG (2010). Geschäftsbericht 2010. Frankfurt am Main.

DB Netz AG (2011). Geschäftsbericht 2011. Frankfurt am Main.

DB Netz AG (2012). Geschäftsbericht 2012. Frankfurt am Main.

DB Netz AG (2013). Geschäftsbericht 2013. Frankfurt am Main.

European Union. (2013). EU Transport in Figures. Statistical Pocketbook 2013. Luxembourg: Publications Office of the European Union. ISBN: 978-92-79-28860-9. DOI: $10.2832 / 19314$.

http://beg.bahnland-bayern.de/

http://epp.eurostat.ec.europa.eu/portal/page/portal/eurostat/home/

http://persoenlicherfahrplan.bahn.de

http://www.bahn.de

http://www.cnb.cz/

http://www.crossrail.co.uk/

http://www.czso.cz

http://www.jizdnirady.cz

http://www.mdcr.cz/cs/verejna-doprava/prehled_o_objednavkach_verejnych_sluzeb/

http://www.mvv-

muenchen.de/fileadmin/media/Dateien/plaene/pdf/Park___Ride_2013.pdf

http://www.ropid.cz/

http://www.verkehr.sachsen.de/

http://www.vvo-online.de/

https://www.regionalstatistik.de/genesis/online/data 